\title{
Comparison of early life history between New Zealand temperate eels and Pacific tropical eels revealed by otolith microstructure and microchemistry
}

\author{
Miho Marui ${ }^{1, *}$, Takaomi Arai $^{1, * *}$, Michael J. Miller ${ }^{1}$, Donald J. Jellyman², \\ Katsumi Tsukamoto ${ }^{1}$
}

\author{
${ }^{1}$ Ocean Research Institute, The University of Tokyo, Minamidai, Nakano, Tokyo 164-8639, Japan \\ ${ }^{2}$ National Institute of Water and Atmospheric Research, PO Box 8602, Christchurch, New Zealand
}

\begin{abstract}
Otolith microstructure and microchemistry were examined in the glass eels of 5 species of Anguilla to compare the early life histories among the New Zealand temperate eels A. dieffenbachii and A. australis, and 3 species of tropical eels (A. bicolor pacifica, A. marmorata and A. celebesensis) collected in Indonesia and the Philippines. The ontogenetic patterns of fluctuation in increment widths and changes in otolith Sr:Ca ratios were similar in all species examined. They all showed an abrupt increase in increment width and a sharp drop in $\mathrm{Sr}$ :Ca ratio, suggesting the onset of metamorphosis from leptocephalus to glass eel. However, age at metamorphosis was different among the 5 species, as was age at recruitment to estuary (average \pm SD), which was $297 \pm 25.3 \mathrm{~d}$ in A. dieffenbachii, $268 \pm 31.3 \mathrm{~d}$ in A. australis, $195 \pm 25.8 \mathrm{~d}$ in A. bicolor pacifica, $170 \pm 15.9 \mathrm{~d}$ in $A$. marmorata and $116 \pm 17.7 \mathrm{~d}$ in $A$. celebesensis. Ages at metamorphosis and recruitment showed a linear relationship in all 5 species, and both of these ages were greater for the New Zealand temperate species than for the tropical eels. A. dieffenbachii recruited to freshwater habitats at the largest size and after the longest larval duration of any species of Anguilla ever reported. This suggests that in New Zealand $A$. dieffenbachii spawns at a location where their leptocephali take longer to reach their freshwater habitat than $A$. australis. This is in contradiction to speculation that $A$. dieffenbachii spawns closer to New Zealand than $A$. australis, based on the more advanced stage of gonadal maturation that has been observed in the silver eels of the former species.
\end{abstract}

KEY WORDS: Eel · Anguilla · Early life history · Otolith · Growth increments · Sr:Ca ratios · Metamorphosis · Inshore migration

\section{INTRODUCTION}

The early life history (glass eel stage) of some species of Anguilla has been well studied using otolith microstructure and microchemistry. The daily deposition of otolith increments has been validated in A. japonica (Tsukamoto 1989, Umezawa et al. 1989), A. rostrata

\footnotetext{
*E-mail: marui@ori.u-tokyo.ac.jp

***Present address: Otsuchi Marine Research Center, Ocean Research Institute, The University of Tokyo, 2-106-1, Akahama, Otsuchi, Iwate 028-1102, Japan
}

(Martin 1995) and A. celebesensis (Arai et al. 2000a). It has also been found that microstructural characteristics such as hatch check (Umezawa et al. 1989), yolk absorption check (Arai et al. 2000a), freshwater check (Kawakami et al. 1998) and a drastic increase in increment width, indicating onset of metamorphosis (Otake et al. 1994, Arai et al. 1997), are useful in interpreting individual life history events. However, this information has been obtained mainly from northern hemisphere temperate eels (A. japonica, A. anguilla and $A$. rostrata), and only recently has the otolith microchemistry of a few Indo-Pacific tropical eel species (Arai et 
al. 1999c,d) and the southern temperate species A. australis (Arai et al. 1999b) been examined in glass eels. There is no information presently available on the early life history of $A$. dieffenbachii, a species endemic to New Zealand, because no leptocephali have ever been collected, despite its freshwater biology being well known (Jellyman 1987).

The objectives of the present study were to examine otolith microstructure and microchemistry in glass eels to compare the early life histories between 2 species of New Zealand eels (Anguilla dieffenbachii and $A$. australis) and 3 species of tropical eels (A. bicolor pacifica, A. marmorata and A. celebesensis) from Indonesia and the Philippines and to compare these findings with previous otolith studies of temperate and tropical eel species. We also report the first information on the early life history of A. dieffenbachii, and compare it to A. australis that is sympatrically distributed in New Zealand.

\section{MATERIALS AND METHODS}

Collection of glass eels. A total of 93 glass eels belonging to 5 species were used in this study (Fig. 1, Table 1). Anguilla dieffenbachii were collected on the South Island of New Zealand in Pigeon Bay Stream on 9 August 1996 and at the mouth of the Arahura River on 22 August 1996, and subsequently on the North Island of New Zealand in the Makara Stream on 4 September 1996. Specimens of A. australis also were collected in the Makara Stream on 4 September 1996. The tropical eels A. bicolor pacifica, A. marmorata and A. celebesensis were caught in the Poigar River, Sulawesi Island, Indonesia, on 13 October 1996 and along the southern coast of Mindanao Island, the Philippines, on 30 January 1998.

All glass eels except the specimens collected in the Philippines were preserved in $99 \%$ ethanol immediately after collection. The specimens from the Philippines were kept in freshwater for several days to a few weeks after collection, and then preserved. Total length, predorsal, preanal and ano-dorsal lengths of each specimen were measured to the nearest $0.1 \mathrm{~mm}$, and pigmentation stages were determined according to Bertin (1956). All specimens were identified morphologically (Ege 1939, Tabeta et al 1976) and genetically (Arai et al. 1999a).

Otolith preparation. Sagittal otoliths were removed from each fish, and prepared for electron microprobe analysis of the Sr:Ca ratios, as described by Arai et al. (1997, 1999b,c,d). Otoliths were embedded in epoxy resin (Struers, Epofix) and mounted on glass slides. A grinding machine equipped with diamond cup wheel (Struers, Discoplan-TS) was then used to obtain a section through the core region of each otolith. The sur- face of each section was then polished with 6 and $1 \mu \mathrm{m}$ diamond paste on an automated polishing wheel (Struers, Planopol-V), cleaned in an ultrasonic bath, and rinsed with deionized water in preparation for subsequent examination.

Otolith X-ray microprobe analysis. For electron microprobe analysis, 50 otoliths from glass eels (2 to 7 specimens from each fish group) were carbon-coated by a high-vacuum evaporator. The concentrations (\% dry weight) of Sr and Ca were measured at $1 \mu \mathrm{m}$ intervals across the longest axis of each otolith using a wavelength-dispersive X-ray electron microprobe (JEOL JXA-733). The accelerating voltage and beam current were $15 \mathrm{kV}$ and $7 \mathrm{nA}$, respectively. The electron beam was focused on a point about $1 \mu \mathrm{m}$ in diameter, and the measurements were spaced at $1 \mu \mathrm{m}$ intervals. Each datum represents the average of 3 measurements (each counting time $=4.0 \mathrm{~s}$ ). Microprobe measurement points, which were seen as burn depressions, were assigned to otolith growth increments identified as described below. The averages of successive data of $\mathrm{Sr}$ and $\mathrm{Ca}$ concentrations pooled for every 10 successive growth increments were used for the life history transect analysis.

Otolith increment analysis. Following the electron microprobe analysis, each otolith was lightly polished with $1 \mu \mathrm{m}$ diamond paste to remove the carbon coating, etched with $0.05 \mathrm{M} \mathrm{HCl}$, and vacuum-coated with

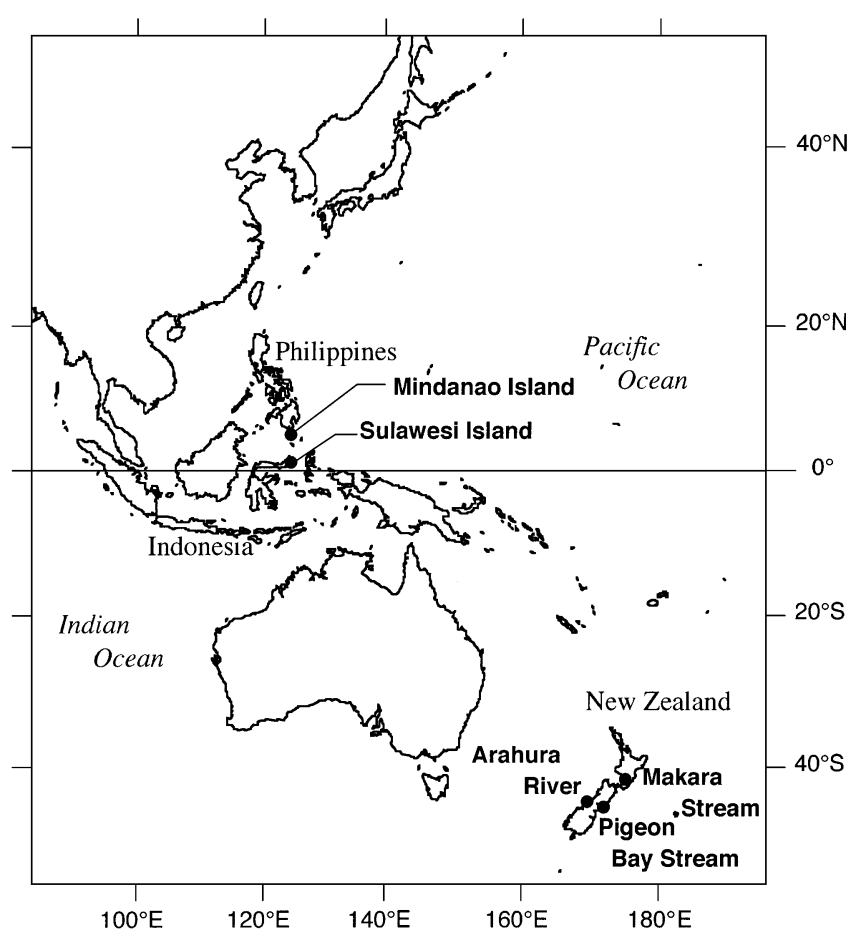

Fig. 1. Map showing sampling locations of temperate glass eels in New Zealand and of tropical glass eels in Indonesia and the Philippines 
Table 1. Anguilla spp. Collection records, pigmentation stages, total length and otolith radius of the specimens used in this study. ${ }^{*}$ Data for 1 individual, (n) no. of specimens examined; - : no data

\begin{tabular}{|c|c|c|c|c|c|c|c|c|c|}
\hline \multirow{2}{*}{$\begin{array}{l}\text { Sampling } \\
\text { location }\end{array}$} & \multirow{2}{*}{$\begin{array}{l}\text { Sampling } \\
\text { date }\end{array}$} & \multirow[t]{2}{*}{ Species } & \multirow[t]{2}{*}{ (n) } & \multicolumn{2}{|c|}{ Pigmentation stages } & \multicolumn{2}{|c|}{ Total length (mm) } & \multicolumn{2}{|c|}{ Otolith radius $(\mu \mathrm{m})$} \\
\hline & & & & VA & $\mathrm{VB}$ & Mean $\pm \mathrm{SD}$ & Range & Mean \pm SD & Range \\
\hline $\begin{array}{l}\text { New Zealand eels } \\
\text { Pigeon Bay stream, } \\
\text { New Zealand }\end{array}$ & 9 Aug 1996 & A. dieffenbachii & $(10)$ & 0 & 10 & $64.4 \pm 2.2$ & $60.8-68.3$ & $156.2 \pm 8.3$ & $143.0-170.7$ \\
\hline $\begin{array}{l}\text { Arahura River, } \\
\text { New Zealand }\end{array}$ & 22 Aug 1996 & A. dieffenbachii & $(10)$ & 5 & 5 & $65.3 \pm 6.3$ & $62.8-71.6$ & $156.2 \pm 8.8$ & $142.6-168.3$ \\
\hline $\begin{array}{l}\text { Makara stream, } \\
\text { New Zealand }\end{array}$ & 4 Sep 1996 & $\begin{array}{l}\text { A. dieffenbachii } \\
\text { A. australis }\end{array}$ & $\begin{array}{r}(2) \\
(10)\end{array}$ & 0 & $\begin{array}{l}2 \\
7\end{array}$ & $\begin{array}{c}68.9^{*} \\
68.5^{*} \\
60.3 \pm 2.2\end{array}$ & $57.0-64.4$ & $\begin{array}{r}153.0^{*} \\
159.3^{*} \\
161.1 \pm 8.4\end{array}$ & $147.3-171.9$ \\
\hline $\begin{array}{l}\text { Tropical eels } \\
\text { Poigar River, } \\
\text { Sulawesi Island, } \\
\text { Indonesia }\end{array}$ & 13 Oct 1996 & $\begin{array}{l}\text { A. marmorata } \\
\text { A. celebesensis }\end{array}$ & $\begin{array}{r}(3) \\
(13) \\
(14)\end{array}$ & $\begin{array}{l}13 \\
13\end{array}$ & $\begin{array}{l}0 \\
1\end{array}$ & $\begin{array}{c}52.0^{*} \\
50.3^{*} \\
52.1^{*} \\
50.8 \pm 1.7 \\
46.6 \pm 1.7\end{array}$ & $\begin{array}{r}48.1-53.7 \\
44.00-50.0\end{array}$ & $\begin{array}{r}126.2^{*} \\
136.5^{*} \\
130.2^{*} \\
134.8 \pm 5.8 \\
118.7 \pm 6.7\end{array}$ & $\begin{array}{l}127.2-145.3 \\
108.1-131.1\end{array}$ \\
\hline $\begin{array}{l}\text { Southern coast, } \\
\text { Mindanao Island, } \\
\text { The Philippines }\end{array}$ & 30 Jan 1998 & $\begin{array}{l}\text { A. bicolor pacifica } \\
\text { A. marmorata } \\
\text { A. celebesensis }\end{array}$ & $\begin{array}{r}(12) \\
(16) \\
(3)\end{array}$ & $\begin{array}{l}- \\
- \\
-\end{array}$ & $\begin{array}{l}- \\
- \\
-\end{array}$ & $\begin{array}{c}48.9 \pm 2.5 \\
48.9 \pm 1.3 \\
41.5^{*} \\
47.0^{*} \\
48.7^{*}\end{array}$ & $\begin{array}{l}44.4-54.4 \\
47.4-51.0\end{array}$ & $\begin{array}{c}165.6 \pm 11.4 \\
150.2 \pm 6.5 \\
166.6^{*} \\
133.9^{*} \\
179.9^{*}\end{array}$ & $\begin{array}{l}143.5-187.1 \\
139.2-160.7\end{array}$ \\
\hline
\end{tabular}

Pt-Pd in an ion-sputterer for scanning electron microscope (SEM) observations. The otolith sections of 43 glass eels that had not been used for X-ray microprobe analysis also were etched and coated in the same way. Each section was viewed with a SEM (Hitachi S-4500), and SEM photographs taken at $1500 \times$ magnification were used for counting the otolith growth increments and measuring their widths. The longest radius of the ground otolith surface was used as the otolith radius along which increment widths were measured. The average of every 10 successive increment widths from the hatch check to the edge was used for otolith growth-increment analysis. Data of Sr and Ca contents around the measurement points were assigned to each 10 growth increments and used for life history transect analysis. Otolith increments of Anguilla japonica (Tsukamoto 1989, Umezawa et al. 1989), A. rostrata (Martin 1995) and A. celebesensis (Arai et al. 2000a) have been validated as being deposited daily, so we assumed that the species studied here also deposited increments daily.

Early life history parameters. The following early life history parameters were determined by otolith analyses: hatching date, and timing of yolk absorption, metamorphosis and recruitment (Fig. 2). Under SEM observation, the hatch check was identified as a deep circular groove surrounding the nucleus, which is the deep hole at the center of the otolith. It has been validated that this check is deposited at the time of hatch- ing in Anguilla japonica (Umezawa et al. 1989). The age at deposition of the hatching check was considered as Day 0. The yolk absorption check was the second check outside the central hole, and was visible as a deep dark groove surrounding a crystalline crown just outside the hatch check in A. celebesensis (Arai et al. 2000a). The innermost check on the otolith edge was regarded as a freshwater check which was formed when the glass eel entered freshwater (Kawakami et al. 1998, Arai et al. 1999b,d). We defined the number of increments between the hatch check and freshwater check as the age at recruitment. In the case of there being no check at otolith edge, we considered increments from hatch check to the edge as age at recruitment. Total age was the number of increments between the hatch check and otolith edge.

\section{RESULTS}

\section{Size and stage of glass eels at recruitment}

The average total lengths of the New Zealand temperate glass eels were significantly larger than the tropical glass eels from Indonesia and the Philippines. The average total lengths were $66.8 \mathrm{~mm}$ in Anguilla dieffenbachii and $60.3 \mathrm{~mm}$ in A. australis. Those of the tropical eels were $50.8 \mathrm{~mm}$ in A. bicolor pacifica, $49.9 \mathrm{~mm}$ in $A$. marmorata and $46.0 \mathrm{~mm}$ in $A$. celebe- 

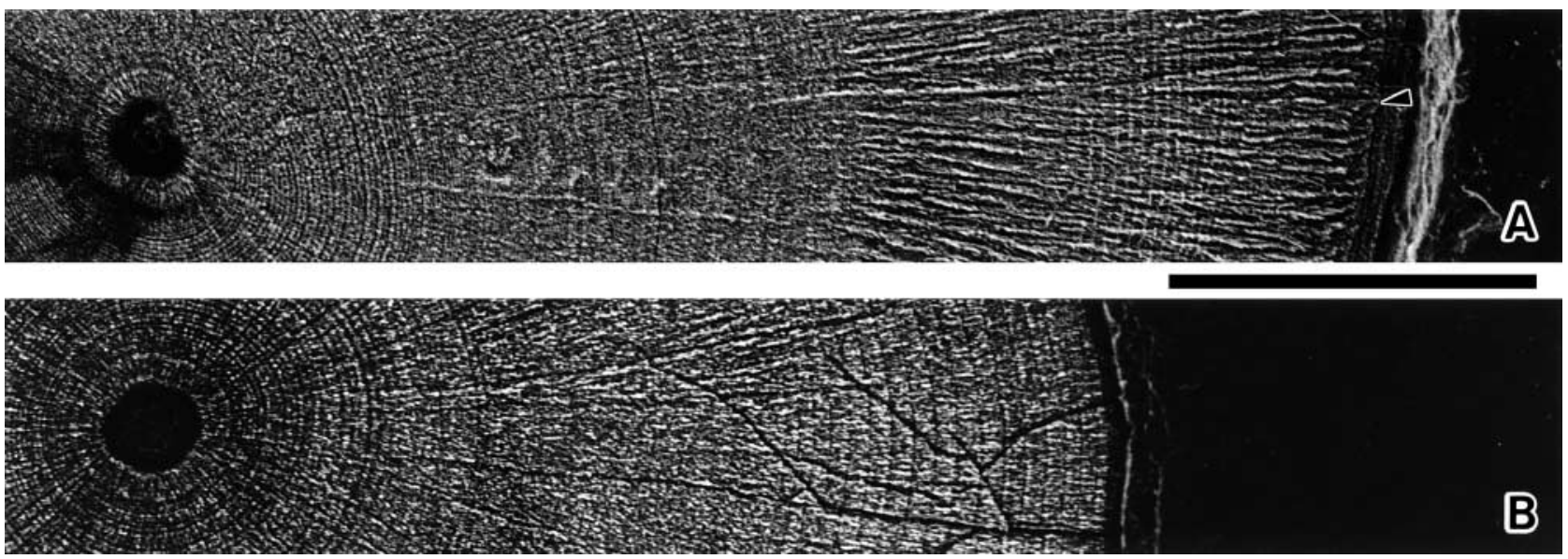

Fig. 2. Anguilla spp. Scanning electron microscope photographs of the microstructure of an etched otolith of (A) an A. dieffenbachii glass eel (57.0 mm total length) collected at the mouth of Makara Stream, and (B) an A. celebesensis glass eel (48.6 mm total length) collected at the mouth of Poigar River. Arrowhead indicates freshwater check. Scale bar $=50 \mu \mathrm{m}$

sensis (Table 1). Both New Zealand species were larger in body size than the tropical species and did not overlap in size ranges. A. dieffenbachii was the largest (ANOVA, $\mathrm{p}<0.0001$ ) and A. celebesensis was the smallest (ANOVA, p < 0.05) among the 5 species. An intraspecific difference in length between localities was found only in A. marmorata from Indonesia and the Philippines (ANOVA, $\mathrm{p}<0.005$ ). No significant difference was found within other species with specimens from different sampling locations (ANOVA, $\mathrm{p}>0.05$ ).

All eels belonged to the pigmentation stage VA to VB (glass eel stage) except for eels sampled in the Philippines, VI AI to VI AIII (elver stage), because these were kept in freshwater for several days to a few weeks after collection at a river mouth before preservation (Table 1).

\section{Otolith morphology}

The otoliths of all glass eels in this study were oval, similar to those observed in other Anguilla spp., but the otolith radii of the New Zealand eels were significantly larger than those of the tropical species. The average otolith radius of New Zealand eels was $156.2 \mu \mathrm{m}$ in A. dieffenbachii, and $161.1 \mu \mathrm{m}$ in A. australis, but those of tropical eels in Indonesia were $131.0 \mu \mathrm{m}$ in A. bicolor pacifica, $134.8 \mu \mathrm{m}$ in A. marmorata and $118.7 \mu \mathrm{m}$ in $A$. celebesensis. The radii of New Zealand eels were significantly larger than those of $A$. bicolor pacifica and A. celebesensis from Indonesia (ANOVA, p < 0.0001; Table 1). However, larger average otolith radii were observed in the tropical eels in the Philippines (165.6 $\mu \mathrm{m}$ in A. bicolor pacifica, $150.2 \mu \mathrm{m}$ in A. marmorata and $160.1 \mu \mathrm{m}$ in A. celebe- sensis), probably because they were held in freshwater before preservation.

Hatch checks were observed in $100 \%$ of the individuals examined irrespective of species and sampling localities, and were similar in average diameter between the temperate and tropical species. The average diameters of the hatch check of the New Zealand eels Anguilla dieffenbachii and A. australis were 10.9 and $11.1 \mu \mathrm{m}$, respectively. Those of $A$. celebesensis, A. marmorata and A. bicolor pacifica, were 10.4, 10.0 and $8.7 \mu \mathrm{m}$, respectively. There was no significant difference in diameters of hatch check among these 5 species $(\mathrm{p}>0.05)$.

The yolk absorption check was observed in 95\% of individuals in this study. The average radius of the check in the 5 species ranged from $10.1 \mu \mathrm{m}$ (Anguilla australis) to $10.7 \mu \mathrm{m}$ (A. bicolor pacifica), showing no difference among species and sampling sites. Average age at yolk absorption in each species ranged from 7.2 to $9.8 \mathrm{~d}$, with individual values ranging from 5 to $15 \mathrm{~d}$ (Table 2).

A freshwater check was observed in the otoliths of $32(100 \%)$ of the New Zealand glass eels (Anguilla dieffenbachii, A. australis) and 31 (100\%) of the tropical glass eels from the Philippines, but only $1 \mathrm{~A}$. bicolor pacifica and $1 \mathrm{~A}$. celebesensis from Indonesia $(7 \%)$ had a freshwater check in their otolith. It is likely that the Philippine specimens had formed the freshwater check when they were held in freshwater after being collected along the coast. The average radius of the freshwater check was $146.8 \mu \mathrm{m}$ in A. dieffenbachii and $153.5 \mu \mathrm{m}$ in A. australis. Those of tropical eels from the Philippines were $148.2 \mu \mathrm{m}$ in A. bicolor pacifica, $137.4 \mu \mathrm{m}$ in A. marmorata and $140.9 \mu \mathrm{m}$ in A. celebesensis. 


\section{Increment width and $\mathrm{Sr}: \mathrm{Ca}$ ratio}

Profiles of otolith increment widths along the life history transects from the hatch check to the edge (or freshwater check) showed 2 peaks in all 5 species (Fig. 3). The 2 peaks in otolith increment widths were present in all the individuals examined, with the first at 30 to $50 \mathrm{~d}$ and the second at 100 to $300 \mathrm{~d}$. The increment widths of the second peaks were greater $(>2 \mu \mathrm{m})$ in tropical eels than in temperate eels $(<2 \mu \mathrm{m})$, although the widths of the first peaks were about the same. The age at which the second peak occurred was greater in temperate eels (ca 200 to $300 \mathrm{~d}$ ) than in tropical eels (ca 100 to $200 \mathrm{~d}$ ), but the first peaks occurred at about the same age in all 5 species.

All species showed a similar pattern of change in $\mathrm{Sr}$ :Ca ratio along life history transects from the otolith core to the edge (Fig. 4). The Sr:Ca ratio generally increased from the core towards the edge, but then decreased after ages greater than about 80 to $200 \mathrm{~d}$, depending on the species. The value of the $\mathrm{Sr}$ :Ca ratios just before the decrease was greater than $10 \times 10^{-3}$ in both temperate and tropical eels. The tropical eel Sr:Ca ratios showed a more abrupt drop at younger ages than the temperate eels, which displayed a slower drop at older ages.

The timing of the abrupt increase in increment width and the drop in the $\mathrm{Sr}$ :Ca ratio coincided exactly in all individuals of all 5 species in this study (Fig. 5). According to a previous study on Anguilla japonica (Arai et al. 1997), metamorphosis starts at the timing of the abrupt increase in increment width and decrease in Sr:Ca ratio. Arai et al. (1997, 1999c,d) found that metamorphosis was completed before the maximum peak of otolith increment width in the temperate eel A. japonica and some tropical eels,

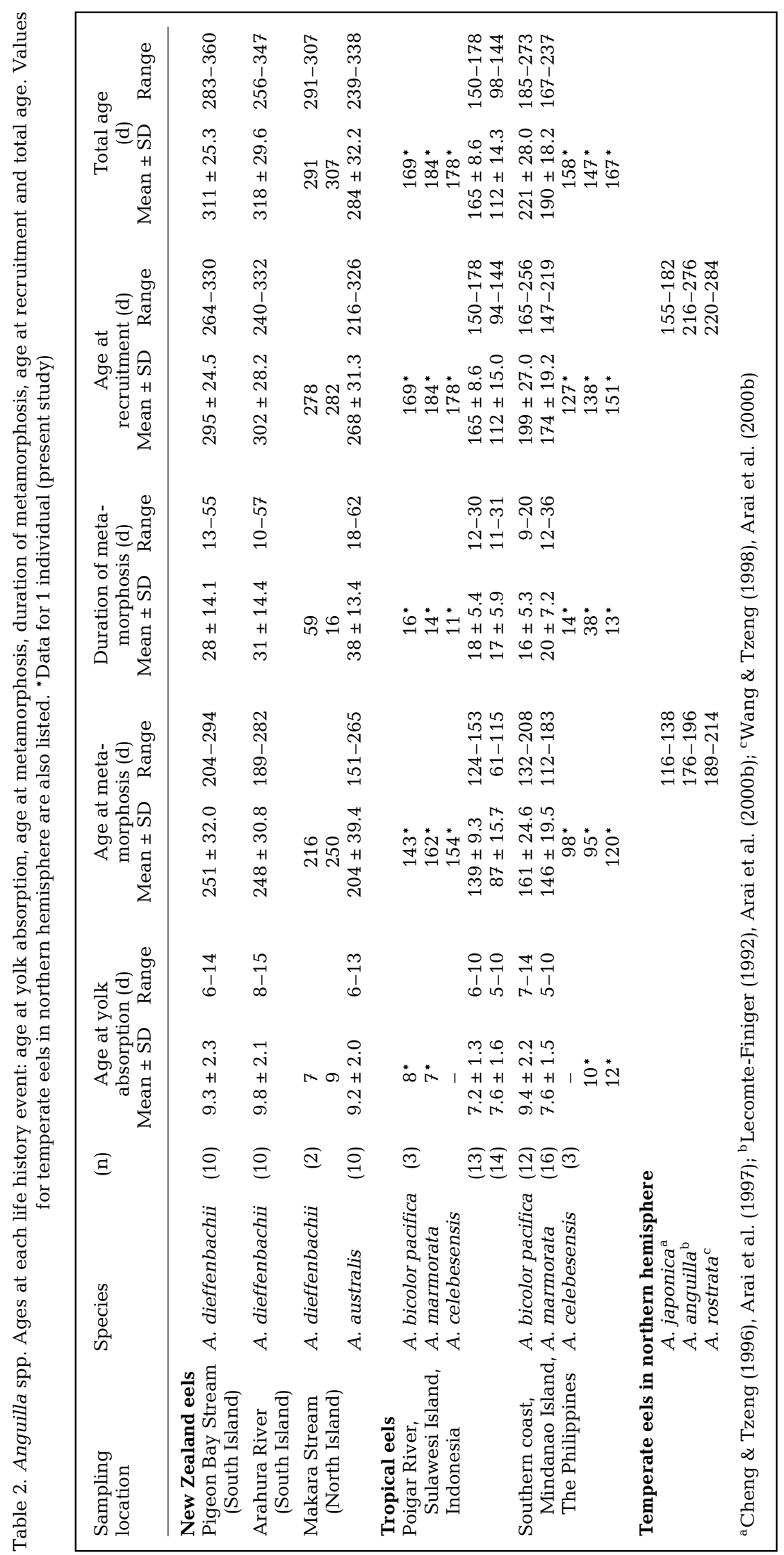




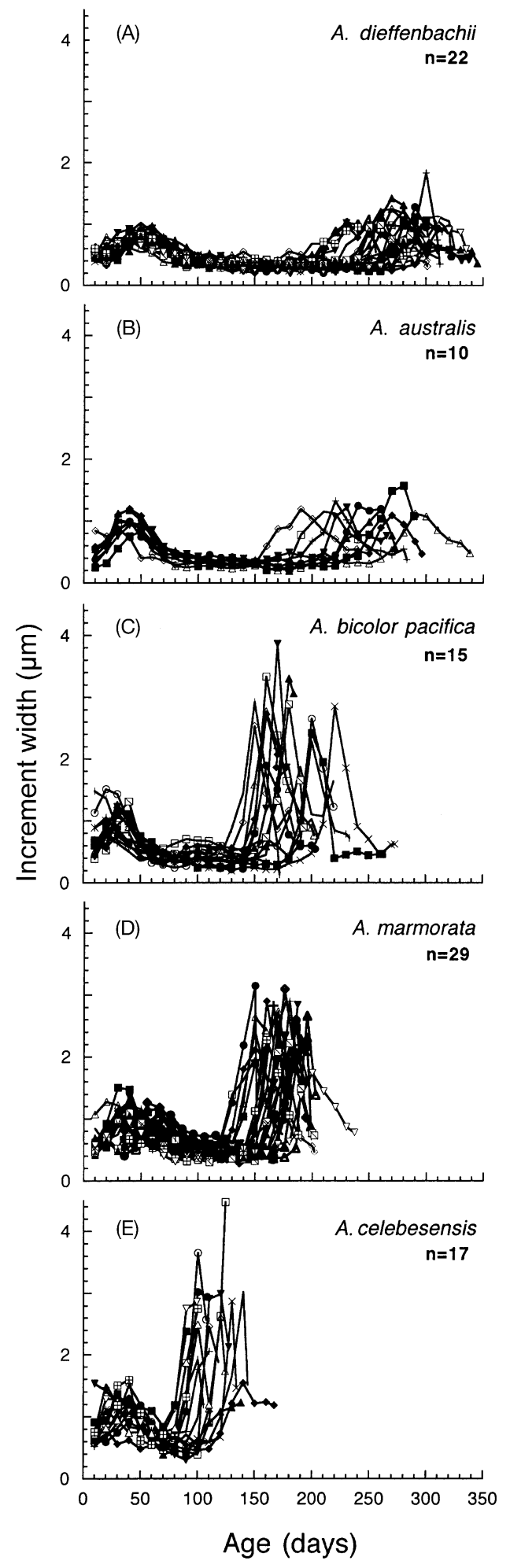

Fig. 3. Anguilla spp. Profiles of otolith incremental width from the core to the edge, or to the freshwater check, in the otoliths of glass eels of the temperate species (A) A. dieffenbachii and (B) A. australis, and the tropical species (C) A. bicolor pacifica, (D) A. marmorata, and (E) A. celebesensis. Each data point represents an average of data for $10 \mathrm{~d}$. Individual symbols represent the different specimen studied since increment width did not markedly decrease from its maximum level in several glass eels recruited to coasts. Thus, the simultaneous change in the otolith increment width and Sr:Ca ratios found in this study indicated that all species we examined start metamorphosis at the timing of the abrupt increase in increment width and decrease in $\mathrm{Sr}$ :Ca ratio.

\section{Metamorphosis and recruitment}

The ages at the onset of metamorphosis differed among all species and were greatest in the New Zealand species. The ages at onset of metamorphosis (average $\pm \mathrm{SD}$ ) were $248 \pm 30.0 \mathrm{~d}$ in Anguilla dieffenbachii, $204 \pm 39.4 \mathrm{~d}$ in $A$. australis, $160 \pm 22.4 \mathrm{~d}$ in A. bicolor pacifica, $143 \pm 15.8 \mathrm{~d}$ in A. marmorata, and $90 \pm 16.5 \mathrm{~d}$ in $A$. celebesensis. There were significant differences among species (ANOVA, $\mathrm{p}<0.01$ ), but not within species that had individuals collected at different sampling sites in either New Zealand or in Indonesia and the Philippines (ANOVA, p > 0.1), despite some apparent differences in ranges (Table 2). Both $A$. dieffenbachii and $A$. australis in New Zealand metamorphosed at greater ages than the tropical eels $A$. bicolor pacifica, A. marmorata and A. celebesensis. The average duration of metamorphosis ranged from 16 (A. bicolor pacifica from Philippines) to $38 \mathrm{~d}$ (A. dieffenbachii from Makara Stream). The duration was significantly longer in New Zealand eels than in tropical eels $(\mathrm{p}<0.0001)$.

The average age at recruitment also differed significantly among all the species and was greatest in the New Zealand eels. The ages at recruitment (average \pm SD) were $297 \pm 25.3 \mathrm{~d}$ in Anguilla dieffenbachii, $268 \pm$ $31.3 \mathrm{~d}$ in A. australis, $195 \pm 25.8 \mathrm{~d}$ in A. bicolor pacifica, $170 \pm 15.9 \mathrm{~d}$ in $A$. marmorata and $116 \pm 17.7 \mathrm{~d}$ in A. celebesensis, with significant differences among species (ANOVA, $\mathrm{p}<0.001$; Table 2). A. dieffenbachii recruited to estuary at the oldest age, and $A$. celebesensis at the youngest age of the 5 species. The age at metamorphosis and ages at recruitment showed a similar linear relationship in all 5 species in that the individuals that metamorphosed at younger ages recruited at younger ages (Fig. 6).

\section{Hatching date}

The estimated hatching dates of each species reflect the different sampling dates at the different locations from which each species was collected. The estimated hatching dates of Anguilla dieffenbachii collected at Pigeon Bay Stream on 9 August 1996 were from 15 August to 28 October 1995; those collected at the Ara- 


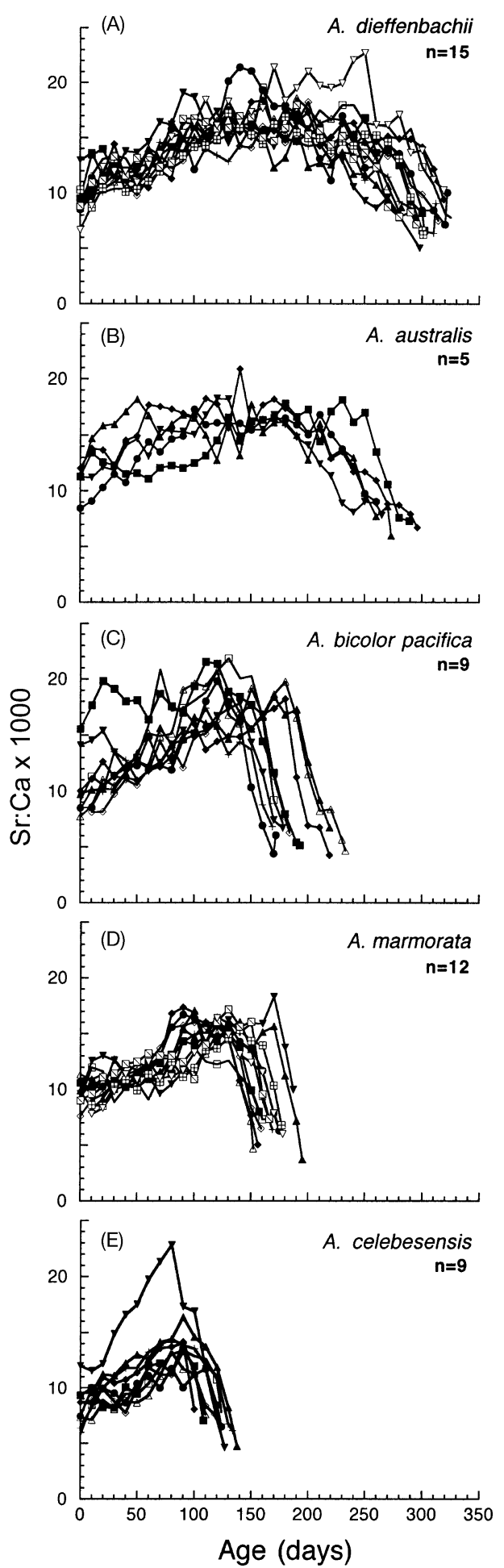

Fig. 4. Anguilla spp. Profiles of otolith Sr:Ca concentration ratios measured with a wavelength dispersive electron microprobe from the core to the edge, or to the freshwater check, in the otoliths of glass eels of the temperate species (A) A. dieffenbachii and (B) A. australis, and the tropical species (C) A. bicolor pacifica, (D) A. marmorata, and (E) A. celebesensis. Each data point represents an average of data for $10 \mathrm{~d}$. Individual symbols represent the different specimen studied

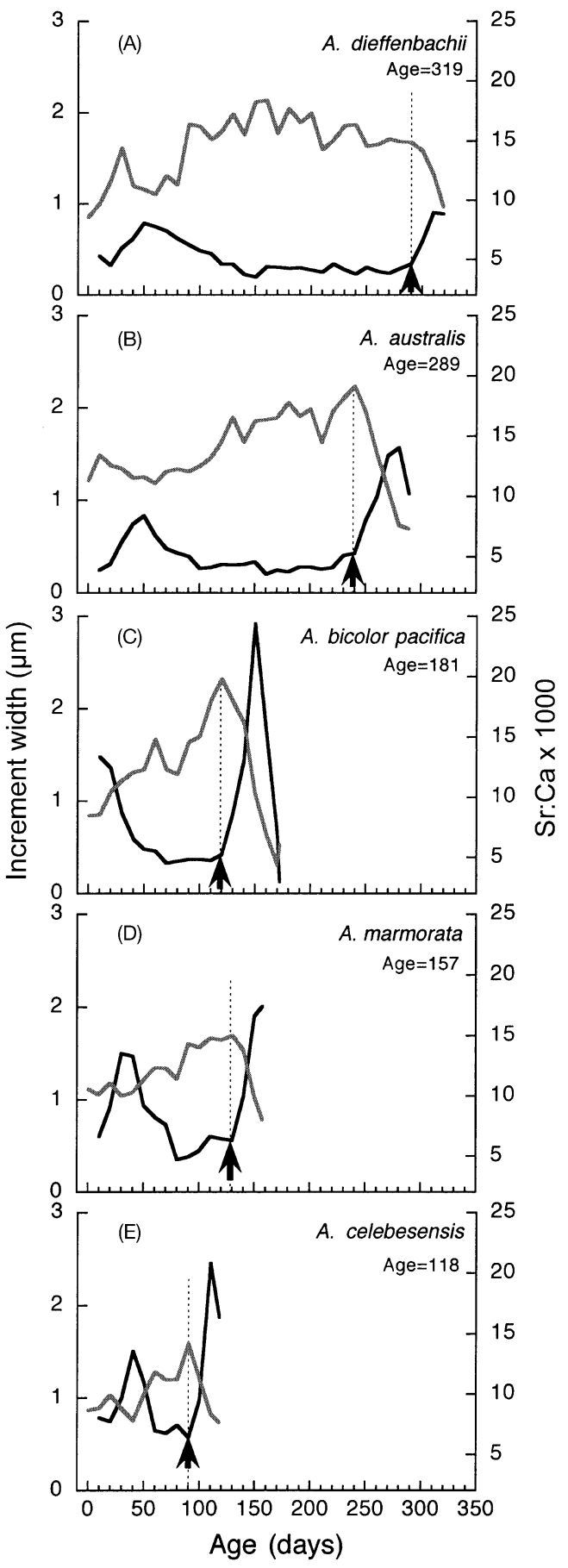

Fig. 5. Anguilla spp. Individual profiles of otolith incremental width (black line) and otolith Sr:Ca concentration ratios (gray line) measured from the core to the edge of an otolith from a glass eel of (A) A. dieffenbachii collected at mouth of Pigeon Bay Stream, (B) A. australis collected at mouth of Makara Stream, (C) A. bicolor pacifica collected along the coast of Mindanao Island, (D) A. marmorata collected along the coast of Mindanao Island, and (E) A. celebesensis collected at mouth of Poigar River. Numbers on upper right of each graph indicate presumed age (d) at time of preservation. Arrow and dotted line indicate age at onset of metamorphosis for each species. (See Fig. 1 for locations of rivers) 


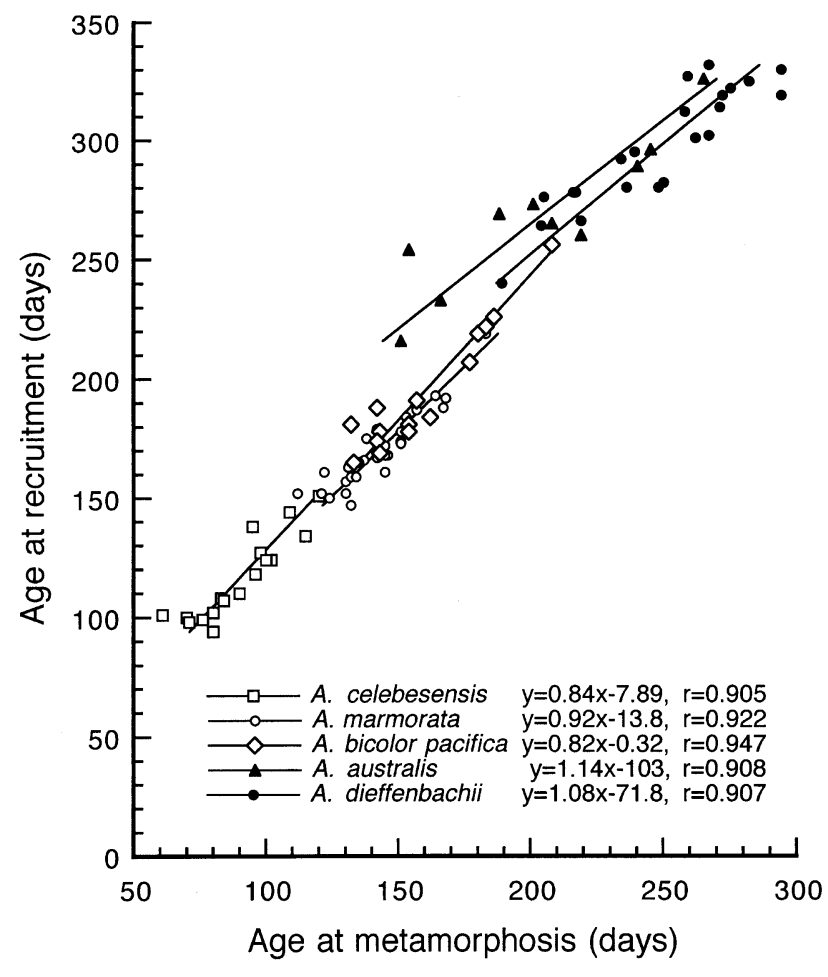

Fig. 6. Anguilla spp. Relationship between age at metamorphosis and age at recruitment, calculated from the otolith microstructure and microchemistry of both temperate and tropical glass eels. A separate regression line has been calculated for each species, with distinct symbols representing each specimen studied

hura River on 22 August 1996 were from 10 September to 10 December 1995; and those collected at the Makara Stream on 4 September 1996 were from 2 to 18 November 1995. The hatching dates of $A$. australis from Makara Stream on 4 September 1996 were from 2 October to 9 January 1996. Those of the tropical eels collected on 13 October 1996 in Indonesia were from 12 to 27 April 1996 for A. bicolor pacifica; 18 April to 16 May 1996 for A. marmorata; and 22 May to 6 July 1996 for A. celebesensis. Those of tropical eels collected on 30 January 1998 in the Philippines were from 7 May to 3 August 1997 for A. bicolor pacifica; 12 June to 21 August 1997 for A. marmorata; and 21 August to 10 September 1997 for A. celebesensis.

\section{DISCUSSION}

\section{Otolith microstructure and microchemistry}

The otoliths of all 5 species of Anguilla examined during this study, irrespective of whether they were temperate or tropical eels, were found to have basically similar microstructural characteristics and growth increment patterns. From center to edge, they had a nucleus, a hatch check, a yolk absorption check, an area of rapid increase in increment width during metamorphosis, and some had a freshwater check (Fig. 2A). All the species studies also showed a linear relationship between the timing of metamorphosis and recruitment, indicating that recruitment occurs at a fairly regular period of time after metamorphosis in each species. These characteristics were similar to those observed in the northern temperate eels $A$. japonica (Otake et al. 1994, Arai et al. 1997), A. anguilla and $A$. rostrata (Arai et al. 2000b), the tropical eel $A$. bicolor pacifica (Arai et al. 1999c), and specimens of A. bicolor bicolor, A. marmorata, A. celebesensis collected at different locations and times (Arai et al. 1999c,d). This suggests that both temperate and tropical species of Anguilla have common developmental stages in their early life history, such as preleptocephalus, leptocephalus, metamorphosing larva and glass eel (Fig. 7), although the duration of each stage differs among species (Fig. 8).

The rapid decrease in $\mathrm{Sr}: \mathrm{Ca}$ ratio and increase in otolith increment width appear to occur during metamorphosis and have been observed in all species of

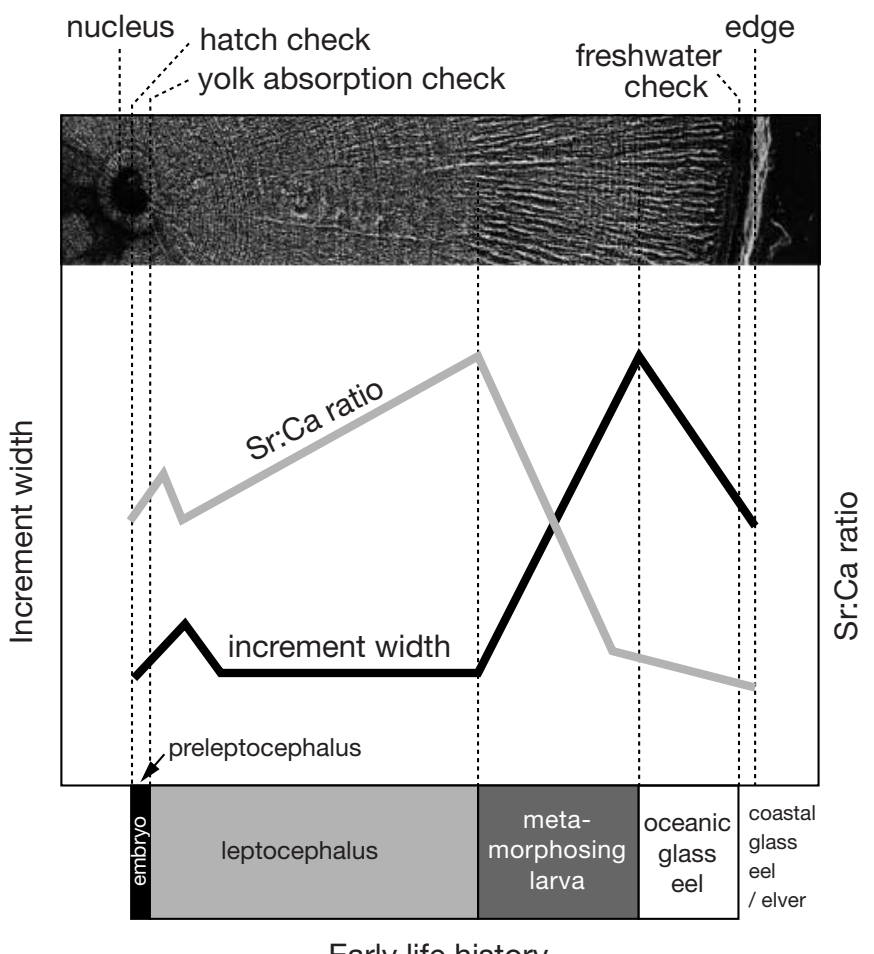

Early life history

Fig. 7. Anguilla spp. Typical microstructure and patterns of change of otolith increment widths and $\mathrm{Sr}$ :Ca ratios observed in the otoliths of glass eels of both temperate and tropical species, showing the location of each early life history stage along the radius of the otolith. Black and gray lines represent increment widths and $\mathrm{Sr}$ :Ca ratios, respectively 


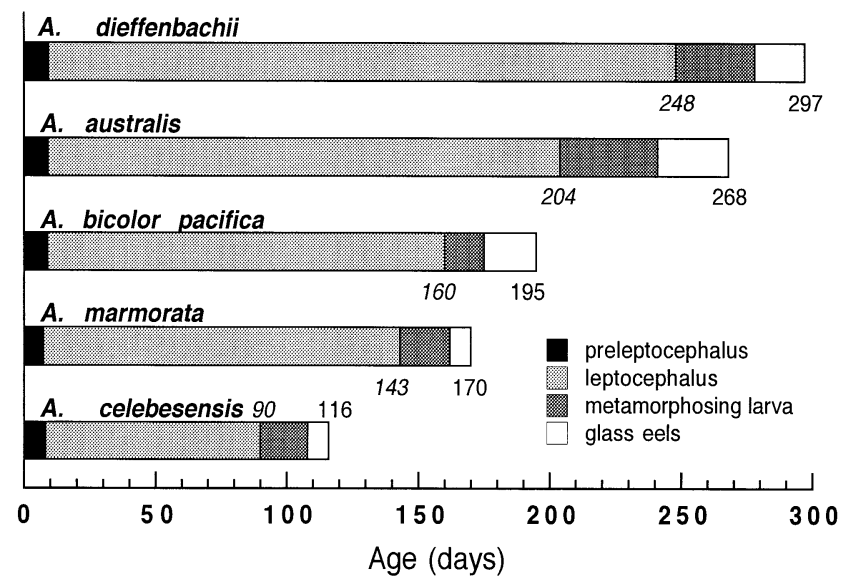

Fig. 8. Anguilla spp. Average ages when the transitions between the various early life history stages occurred in the 5 species examined in the present study. Numbers indicate average age at metamorphosis (italics) and age at recruitment for each species

anguilliform fishes that have been examined. These changes have now been observed in Anguilla japonica (Otake et al. 1994, Arai et al. 1997), A. anguilla and A. rostrata (Arai et al. 2000b), A. australis (Arai et al. 1999b), A. dieffenbachii and the tropical eels A. bicolor bicolor (Arai et al. 1999d), A. bicolor pacifica and specimens of $A$. marmorata and $A$. celebesensis during this study and those collected at different locations and times (Arai et al. 1999d). In addition, similar increases in otolith increment widths have been observed at the beginning of metamorphosis in the conger eel Conger myriaster (Lee \& Byun 1996) as well as simultaneous drastic decreases in the Sr:Ca ratio (Otake et al. 1997). These findings suggest that these changes are a common feature of metamorphosis in anguilliform fishes that may be associated with the remarkable morphological transformation that occurs during metamorphosis. Otake et al. $(1994,1997)$ have proposed that the rapid decrease in $\mathrm{Sr}$ :Ca ratios may be associated with decreasing $\mathrm{Sr}$ levels in the body as a result of catabolism of Sr-rich sulfated glycosamminoglycans during metamorphosis.

\section{Differences among temperate and tropical eels}

Although the general otolith microstructure and patterns of changes in the $\mathrm{Sr}$ :Ca ratios were similar between the temperate and tropical species that were studied, the southern temperate species from New Zealand took a significantly longer time before metamorphosis and recruitment (Fig. 8), and entered freshwater habitats at much larger sizes than the tropical species. The 2 temperate species, Anguilla australis and $A$. dieffenbachii, metamorphosed and recruited on average after 204 and $248 \mathrm{~d}$, and 268 and $297 \mathrm{~d}$, respectively, compared to 90 to 160 and 116 to $195 \mathrm{~d}$, respectively, for the 3 tropical species. The glass eels of both species of New Zealand eels were also much larger at recruitment ( 57.0 to $71.6 \mathrm{~mm}$ ) than those of the 3 tropical species studied here (41.5 to $54.4 \mathrm{~mm}$ ). This indicates that the size of glass eels at recruitment is probably related to the duration of the larval stage, which is longer in the temperate species than in tropical species.

This is the first study of the otolith microstructure and microchemistry of Anguilla dieffenbachii, and it has shown that the duration of the larval period and the time before recruitment was longer in this species, and to a lesser extent in A. australis, than in any other species of Anguilla studied (Fig. 9). A. dieffenbachii took 240 to $332 \mathrm{~d}$ for the onset of recruitment to freshwater, compared to periods for previously studied northern temperate eels of 155 to $182 \mathrm{~d}$ for A. japonica (Tabeta et al. 1987, Tzeng 1990, Cheng \& Tzeng 1996, Arai et al. 1997), 216 to $276 \mathrm{~d}$ for A. anguilla (LecomteFiniger 1992, Arai et al. 2000b), and 220 to $284 \mathrm{~d}$ for $A$. rostrata (Wang \& Tzeng 1998, Arai et al. 2000b; Fig. 9). Similarly, the total length of the glass eel stage of $A$. dieffenbachii (60.8 to $71.6 \mathrm{~mm}$ ) was larger than for $A$. australis (57.0 to $64.4 \mathrm{~mm}$ ) and for any other species of Anguilla, except A. anguilla (64.3 to $69.2 \mathrm{~mm}$ : LecomteFiniger 1992).

The results of this study also indicate that there appears to be some intraspecific differences in the time before recruitment between the glass eel stage of Anguilla australis from different locations in New Zealand and Australia, and between glass eels of some tropical eel species, which have been studied previously at different sampling locations and times of year. The ages at recruitment to freshwater of at least some specimens of $A$. australis collected at the southern end of the North Island of New Zealand during this study (average: $268 \pm 31.3 \mathrm{~d}$, range $=216$ to $326 \mathrm{~d}$ ) were greater than those from the western coast of the South Island of New Zealand ( $232 \pm 19.8 \mathrm{~d}, 214$ to $263 \mathrm{~d}$ ), the eastern coast of the South Island $(237 \pm 20.0 \mathrm{~d}, 208$ to $266 \mathrm{~d})$ and from Australia (208 \pm 17.4 d, 186 to 239 d) that same year (Arai et al. 1999b). Similarly, A. celebesensis sampled on Sulawesi Island, Indonesia, on 13 October 1996 during this study, had an average age at recruitment of $112 \pm 15.0 \mathrm{~d}$ (range $=94$ to $144 \mathrm{~d}$ ), but $A$. celebesensis sampled in the Cagayan River at the northern edge of the Philippines on 24 September 1994 had a greater average age at recruitment of $157 \pm$ $13.7 \mathrm{~d}$ (range $=130$ to $177 \mathrm{~d}$ ) (Arai et al. 1999d). A. marmorata also showed differences between its ranges in age at recruitment in the samples from the 2 locations during this study (Fig. 9) and greater ages at re- 

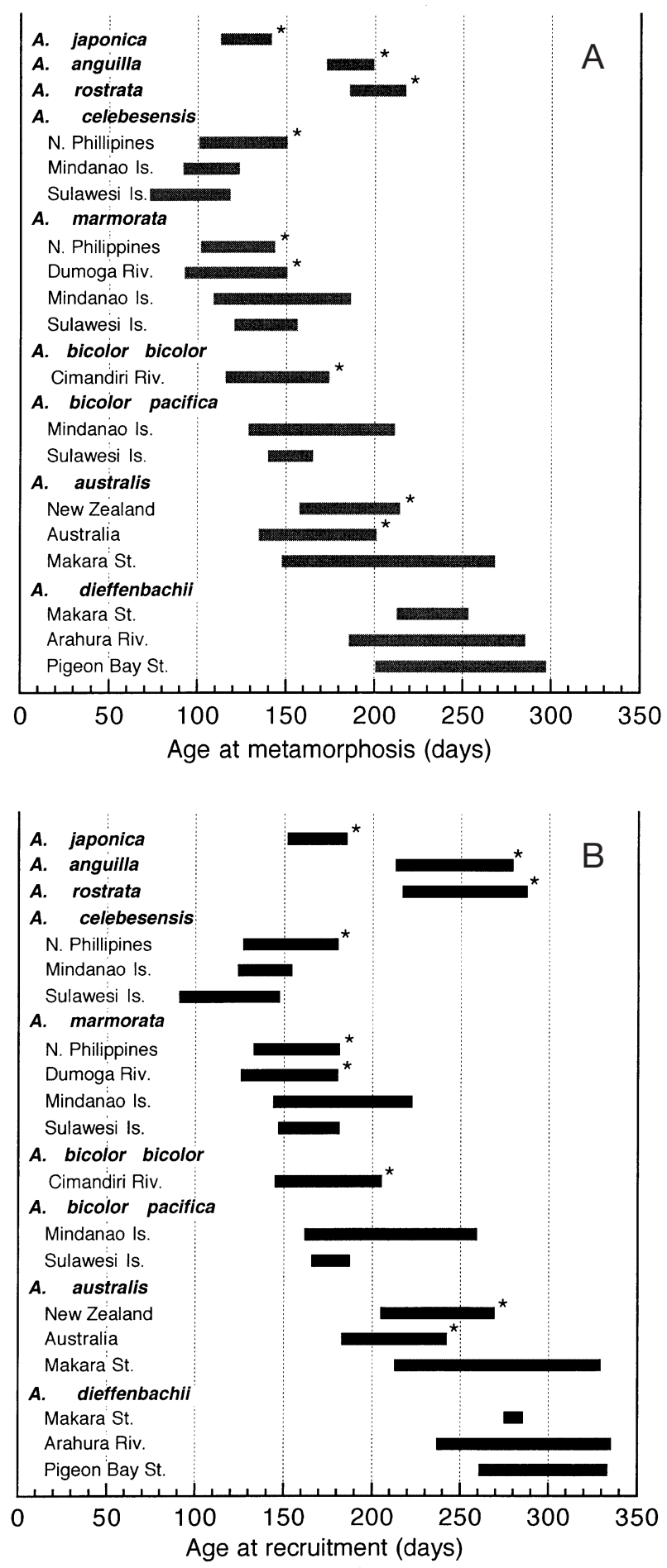

Fig. 9. Anguilla spp. Ranges in (A) age at metamorphosis and (B) age at recruitment based on SEM analyses of the otolith microstructure of temperate and tropical species from the present and previous studies (A. japonica: Tabeta et al. 1987, Tzeng 1990, Cheng \& Tzeng 1996, Arai et al. 1997; A. anguilla: Lecomte-Finiger 1992, Arai et al. 2000b; A. rostrata: Wang \& Tzeng 1998, Arai et al. 2000b; A. celebesensis: Arai et al. 1999d; A. marmorata: Arai et al. 1999d; A. bicolor bicolor: Arai et al. 1999d; A. australis: Arai et al. 1999b). ${ }^{*}$ Previous studies cruitment than previously determined by Arai et al. (1999d). The specimens from the southern edge of the Philippines, collected during this study on 30 January 1998 had an average age at recruitment of $174 \pm 19.2 \mathrm{~d}$ (range $=147$ to $219 \mathrm{~d}$ ), but the specimens collected from the northern edge of the Philippines on 24 September 1994 had a lower average age at recruitment of $154 \pm 13.5$ d (range $=136$ to 178). Smaller differences were observed between the specimens from the Poigar River on Sulawesi Island, collected during this study on 13 October 1996, which had an average age at recruitment of $165 \pm 8.6 \mathrm{~d}$ (range $=150$ to $178 \mathrm{~d}$ ), and the specimens collected from the nearby Dumoga River on the same island on 5 June 1996, which had an average age at recruitment of $152 \pm 15.2 \mathrm{~d}($ range $=129$ to $177 \mathrm{~d})$.

\section{Life history implications}

The otolith microstructure of the 2 species of eels from New Zealand indicated that Anguilla dieffenbachii has a longer larval duration and time before recruitment than $A$. australis, which is contradictory to previous speculation that $A$. dieffenbachii has a spawning area closer to New Zealand. The migrating silver eels of $A$. australis leave freshwaters in New Zealand from February to April, and those of $A$. dieffenbachii leave in April and May (Jellyman 1987), but the gonad-somatic index of the latter was found to be much higher (Todd 1981). Due to the difference in timing of downstream migration of adult eels of these species and the relative maturity of their silver eels, it has been suggested that $A$. dieffenbachii might spawn closer to New Zealand than A. australis because the glass eels of both species simultaneously begin entering freshwaters in August each year (Todd 1981, Jellyman 1987). It has also been proposed that the size of the glass eel stage of $A$. dieffenbachii is much larger than that of $A$. australis due to a longer larval life resulting from earlier spawning at a closer site, but that glass eels of the former species might have a slower larval migration back to New Zealand or might remain in coastal waters longer before entering freshwaters (Jellyman 1987). The results from this study and those of Arai et al. (1999b) support Jellyman's expectation of a longer larval life for $A$. dieffenbachii, but further speculation about how both species arrive simultaneously is difficult because little is known about the behavior or distribution of anguillid glass eels in coastal waters prior to their recruitment into freshwater.

Further complicating interpretation of the life history implications of data on the New Zealand eels is the fact that no leptocephali of Anguilla dieffenbachii have ever been collected, despite the collection of a few leptocephali of $A$. australis in the South Equatorial Cur- 
rent region, well to the north of New Zealand. All species of Anguilla are thought to spawn in tropical areas (Schmidt 1922, Jespersen 1942, Tsukamoto 1992), and the long duration of the larval phase of the New Zealand temperate eels and the locations of the A. australis leptocephali that have been collected do at least indicate that $A$. australis migrates north to warmer water to spawn. The 3 leptocephali of $A$. australis previously collected from the north of New Zealand were caught between 12 and $25^{\circ} \mathrm{S}$ at about $170^{\circ} \mathrm{E}$, with the smallest specimen $(24.6 \mathrm{~mm})$ being collected in late September (see Jellyman 1987). Nine other leptocephali (20.5 to $32.2 \mathrm{~mm}$ ) collected at $14^{\circ} \mathrm{S}$ and $160^{\circ} \mathrm{E}$ in early September were genetically identified as $A$. australis (Aoyama et al. 1999). These leptocephali suggest that this species spawns within the South Equatorial Current, as has been discussed by previous authors (Jellyman 1987, Aoyama et al. 1999, Arai et al. 1999b). However, further larval sampling over a wider area in the South Pacific will be required to locate the spawning area of $A$. dieffenbachii and understand the life histories of the 2 New Zealand eel species.

In contrast to the regular seasonal patterns of adult spawning migration and subsequent recruitment of the glass eels of the New Zealand eels, the tropical species of Anguilla appear to have multiple spawning periods, with their glass eel stage recruiting to freshwater throughout most of the year, and presumably have much shorter spawning migrations. The projected hatching dates of the glass eels of the 3 tropical species sampled during this study in October and January ranged from April to September, and other otolith studies of tropical glass eels found projected hatching dates ranging from April to May and November to March (Arai et al. 1999c,d), which suggests there is no exclusive spawning season for these tropical eels. In addition, the 3 tropical species studied here have been found to recruit into freshwater at the Poigar River, Sulawesi Island, Indonesia (Fig. 1), throughout the year in varying abundances, indicating almost year-round spawning for A. marmorata and A. celebesensis (Arai et al. 1999a). The greatest abundance of $A$. marmorata and A. celebesensis during recruitment was in June, but that of A. bicolor pacifica was much more sporadic. Jespersen (1942) found leptocephali of tropical eel species of a wide range of sizes present from September to November south of Sumatra, indicating that the anguillid eels in that region were spawning over a relatively long time period. Small larvae $<20 \mathrm{~mm}$ were collected over deep water relatively close to the shore south of Sumatra, but not at stations farther offshore (Jespersen 1942), suggesting that some tropical eels make relatively short migrations to spawn over deep water near their adult habitats. Additional sampling for small leptocephali will be required to identify the spawning locations of tropical eels that live in other areas of the Indo-Pacific region and to identify relationships between spawning location, the duration of the larval stage of each species or regional population and the complex pattern of surface currents in the region.

Acknowledgements. We are grateful to the late Dr P. H. J. Castle and to Dr T. Otake and Dr D. Limbong, who helped collect the New Zealand eel and tropical eel samples, respectively. This work was supported in part by Grants-in-Aid Nos. 07306022, 07556046, 08041139 and 08456094 from the Ministry of Education, Science, Sports and Culture, Japan, Research for the Future Program No. JSPS-RFTF 97L00901 from the Japan Society for the Promotion of Science, the Eel Research Foundation from Nobori-kai, and the Research Foundation from Touwa Shokuhin Shinkoukai. Partial support was also given in the form of a Research Fellowship from the Japan Society for the Promotion of Science for Young Scientists to T.A.

\section{LITERATURE CITED}

Aoyama J, Mochioka N, Otake T, Ishikawa S, Kawakami Y, Castle PHJ, Nishida M, Tsukamoto K (1999) Distribution and dispersal of anguillid leptocephali in the western Pacific Ocean revealed by molecular analysis. Mar Ecol Prog Ser 188:193-200

Arai T, Otake T, Tsukamoto K (1997) Drastic changes in otolith microstructure and microchemistry accompanying the onset of metamorphosis in the Japanese eel Anguilla japonica. Mar Ecol Prog Ser 161:17-22

Arai T, Aoyama J, Limbong D, Tsukamoto K (1999a) Species composition and inshore migration of tropical eels, Anguilla spp., recruiting to the estuary of the Poigar River, Sulawesi Island. Mar Ecol Prog Ser 188:299-303

Arai T, Otake T, Jellyman DJ, Tsukamoto K (1999b) Differences in the early life history of the Australasian shortfinned eel, Anguilla australis from Australia and New Zealand, as revealed by otolith microstructure and microchemistry. Mar Biol 135:381-389

Arai T, Otake T, Limbong D, Tsukamoto K (1999c) Early life history and recruitment of the tropical eel, Anguilla bicolor pacifica, as revealed by otolith microstructure and microchemistry. Mar Biol 133:319-326

Arai T, Limbong D, Otake T, Tsukamoto K (1999d) Metamorphosis and inshore migration of tropical eels, Anguilla spp., in the Indo-Pacific. Mar Ecol Prog Ser 182:283-293

Arai T, Limbong D, Tsukamoto K (2000a) Validation of otolith daily increments in the tropical eel, Anguilla celebesensis. Can J Zool 78:1078-1084

Arai T, Otake T, Tsukamoto K (2000b) Timing of metamorphosis and larval segregation of the Atlantic eels, Anguilla rostrata and $A$. anguilla, as revealed by otolith microstructure and microchemistry. Mar Biol 137:39-45

Bertin L (1956) Eels — a biological study. Cleaver-Hume Press Ltd, London

Cheng PW, Tzeng WN (1996) Timing of metamorphosis and estuarine arrival across the dispersal range of the Japanese eel Anguilla japonica. Mar Ecol Prog Ser 131:87-96

Ege V (1939) A revision of the genus Anguilla Shaw. Dana Rep 16(13):8-256

Jellyman DJ (1987) Review of the marine life history of Australian temperate species of Anguilla. Am Fish Soc Symp 1:276-285 
Jespersen P (1942) Indo-Pacific leptocephali of the genus Anguilla. Dana Rep 22:1-128

Kawakami Y, Mochioka N, Morishita K, Toh H, Nakazono A (1998) Determination of the freshwater mark in otoliths of Japanese eel elvers using microstructure and Sr/Ca ratios. Environ Biol Fish 53:421-427

Lecomte-Finiger R (1992) Growth history and age at recruitment of European glass eels (Anguilla anguilla) as revealed by otolith microstructure. Mar Biol 114:205-210

Lee TW, Byun JS (1996) Microstructural growth in otoliths of conger eel (Conger myriaster) leptocephali during the metamorphic stage. Mar Biol 125:259-268

Martin MH (1995) Validation of daily growth increments in otoliths of Anguilla rostrata (Lesueur) elvers. Can J Zool 73:208-211

Otake T, Ishii T, Nakahara M, Nakamura R (1994) Drastic changes in otolith strontium/calcium ratios in leptocephali and glass eels of Japanese eel Anguilla japonica. Mar Ecol Prog Ser 112:189-193

Otake T, Ishii T, Ishii T, Nakahara M, Nakamura R (1997) Changes in otolith strontium:calcium ratios in metamorphosing Conger myriaster leptocephali. Mar Biol 128: $565-575$

Schmidt J (1922) The breeding places of the eel. Phil Trans R Soc Lond B Biol Sci 211:178-208

Editorial responsibility: Otto Kinne (Editor),

Oldendorf/Luhe, Germany
Tabeta O, Takai T, Matsui I (1976) The sectional counts of vertebrae in the anguillid elvers. Jpn J Ichthyol 22: $195-200$

Tabeta O, Tanaka K, Yamada J, Tzeng WN (1987) Aspects of the early life history of the Japanese eel Anguilla japonica determined from otolith microstructure. Bull Jpn Soc Sci Fish 53:1727-1734

Todd PR (1981) Morphometric changes, gonad histology, and fecundity estimates in migrating New Zealand freshwater eels (Anguilla spp.). NZ J Mar Freshw Res 15:155-170

Tsukamoto K (1989) Otolith daily growth increments in the Japanese eel. Bull Jpn Soc Sci Fish 55:1017-1021

Tsukamoto K (1992) Discovery of the spawning area for the Japanese eel. Nature 356:789-791

Tzeng WN (1990) Relationship between growth rate and age at recruitment of Anguilla japonica elvers in a Taiwan estuary as inferred from otolith growth increments. Mar Biol 107:75-81

Umezawa A, Tsukamoto K, Tabeta O, Yamakawa H (1989) Daily growth increments in the larval otolith of the Japanese eel, Anguilla japonica. Jpn J Ichthyol 35:440-444

Wang CH, Tzeng WN (1998) Interpretation of geographic variation in size of American eel Anguilla rostrata elvers on the Atlantic coast of North America using their life history and otolith aging. Mar Ecol Prog Ser 168:35-43

Submitted: July 6, 2000; Accepted: October 18, 2000

Proofs received from author(s): March 5, 2001 